\title{
GIORGIO VASARI: (N)O ALVORECER DA ERA DA ARTE
}

\section{CHARLISTON NASCIMENTO ${ }^{1}$}

RESUMO: "Le Vite" (As Vidas), de Giorgio Vasari, é reconhecidamente um dos textos mais relevantes da história da arte. Sob a perspectiva de biografar os mais renomados pintores, escultores e arquitetos de sua época, o texto vasariano se tornou célebre tanto como uma primeira história da arte, como o registro basilar para o estudo da arte italiana renascentista e, por fim, também para a compreensão do desenvolvimento e entendimento da arte em um de seus períodos históricos mais proeminentes, qual seja, a arte italiana de Cimabue a Michelangelo Buonarroti. Esses fatos podem nos conduzir a uma interpretação equivocada: a de que o texto de Vasari seja uma obra delimitada ao mero estudo histórico e artefatual, de modo que expandir a compreensão dos fenômenos que aquela obra abarca para os problemas filosóficos da arte de nosso tempo ou da arte em geral constituiria uma tarefa fadada ao anacronismo. No presente artigo, demonstraremos como "Le Vite", pelo contrário, alicerça o conceito de era da arte para uma das principais filosofias da arte contemporânea, qual seja, o essencialismo histórico de Arthur Danto, e em seguida defenderemos em que medida naquela obra do Cinquecento já se fazem presentes e em germinação alguns dos principais aspectos da nossa compreensão atual do termo arte.

PALAVRAS-CHAVE: Arte; Vasari; Danto; história da arte; definição da arte.

ABSTRACT: "Le Vite" (The Lives) by Giorgio Vasari, is recognized as one of the most relevant writings of art history. From the attempt to report the biographies of the most renowned painters, sculptors and architects of his time, the Vasarian book became recognized both as a first art history, as the basic record for the study of Italian Renaissance art and finally also for the understanding of the development and understanding of art in one of its most prominent historical periods, namely, the Italian art from Cimabue to Michelangelo Buonarroti. These facts can lead us to a misinterpretation: that Vasari's writing is a work limited to mere historical and artefactual study, so that expanding the understanding of the phenomena that book encompasses to the philosophical of art problems of our time, or art problems of art in general, would constitute a task doomed to anachronism. Otherwise, in this paper we'll demonstrate how "Le Vite" underlies the concept of age of art for one of the most important philosophies of contemporary art, namely Arthur Danto's essentialism and historicism, and then we will defend in what sense that Cinquecento's work is already present and in germination some of the first aspects of our current understanding of art concept.

KEYWORDS: Art; Vasari; Danto; art history; art definition.

\footnotetext{
${ }^{1}$ Professor de Filosofia da Universidade Estadual de Feira de Santana (UEFS). Doutorando em Filosofia pela Universidade Federal de Minas Gerais (UFMG). Membro associado da Associação Brasileira de Estética (ABRE), da American Society for Aesthetics (ASA) e da International Association for Aesthetics (IAA). E-mail: cpnascimento@uefs.br.
} 
A obra "Le Vite" (As Vidas), do arquiteto e pintor aretino Giorgio Vasari, é comumente aceita como o primeiro escrito de história da arte. Publicada por Lorenzo Torrentino em 1550, sob o longo título "As vidas dos mais renomados arquitetos, pintores e escultores italianos, de Cimabue aos dias atuais, descritas na língua toscana por Giorgio Vasari, pintor de Arezzo. Com uma introdução útil e necessária às suas artes" ${ }^{2}$, e dividida em três partes, sendo a primeira dedicada a um tratado sobre a natureza e os procedimentos arquitetônicos, escultóricos, e de desenho e pintura, e as duas partes seguintes se propondo a oferecer uma espécie de biografia da vida e dos feitos dos artistas historiografados, o grande escrito de Vasari sofre historicamente dois tipos de interpretações valorativas.

De acordo com uma primeira perspectiva, resultante dos estudos do texto vasariano a partir do século XVI até a primeira metade do século XX, os escritos de "Le Vite" correspondem à primeira e mais fidedigna fonte para a compreensão da arte renascentista e de seus criadores mais emblemáticos, ao passo que para um segundo grupo, historicamente localizados a partir da primeira metade do século $\mathrm{XX}$, o texto vasariano seria muito menos relevante para a compreensão da complexidade da arte daquele período icônico em razão dos malefícios que a adoção de um método instrumental pelo arquiteto de Palazzo degli Uffizi implicaram para o texto: demasiada presença dos valores artísticos do autor, imprecisões históricas e certo condicionamento dos biografados às cercanias de Florença.

No que diz respeito a essa primeira perspectiva valorativa sobre o texto de Vasari, seus defensores ressaltam o caráter inovador de sua iniciativa e sua conseguinte influência. Ao descrever as vidas dos mais renomados pintores, arquitetos e escultores de sua era, tarefa esta que exigiu do autor o estabelecimento de um juízo crítico para a seleção dos artistas de relevância para serem biografados, Vasari estabeleceu critérios que os tornava dignos de se

\footnotetext{
${ }^{2}$ N.a.: Deve-se ressaltar que o livro de Vasari, cujo título original é "Le Vite de' piú eccellenti architetti, pittori, et scultori italiani, da Cimabue insino a' tempi nostri, descritte in lingua Toscana, da Giorgio Vasari Pittore Aretino. Con una sua utile et necessaria introduzzione a le arti loro" obteve duas versões realizadas pelo próprio autor, a de 1550, acima, e a de 1569, com o acréscimo "Di nuovo dal medesimo riviste et ampliate, con i ritratti loro, et con l'aggiunta deLe Vite de' vivi, e de' morti dall'anno 1550 infinito al 1567" (Novamente do mesmo período, revistas e ampliadas, com seus retratos e com o acréscimo das vidas dos vivos e dos mortos do ano de 1550 a 1567). Apesar de as revisões e ampliações textuais, mais o acréscimo de ilustrações retratando os artistas biografados, além do acréscimo de novas biografias decorrentes do período de 1550 a 1567 denotarem que a passagem da primeira para a segunda edição decorreu tão-somente em vista da boa receptividade da primeira publicação, é consenso da maior parte dos estudiosos que a revisão efetuada por Vasari modificou bastante a estrutura do texto, no sentido que enquanto a primeira possuía um caráter mais puro e artístico, na segunda se acrescentou, corrigiu e normatizou-se bastante o texto, tornando-o em certa medida acumulativo (Cf. Previtali, G. In. VASARI, 2011, p.XI).
} 
fazerem presentes em uma narrativa de ordem histórica, distinguindo-os e elevando-os em relação a toda uma gama de outros praticantes do mesmo ofício. Sejam esses critérios pouco objetivos, ou mesmo dignos de questionamentos, o fato é que o texto de Vasari estabeleceu um paradigma necessário para toda e qualquer narrativa histórica da arte futura, qual seja, o de que uma narrativa histórica de um determinado ofício não deve conter a totalidade dos praticantes daquele ofício, mas de uma seleção daqueles que são representativos dessa arte em sua época. De acordo com Giovanni Previtali:

Vasari foi e quis ser, acima de tudo, historiador e, ao lado dos escritores de história, não se contentou em narrar simplesmente os casos ocorridos, sem interpor em parte alguma o seu juízo, mas quis não só dizer o que os artistas fizeram, como também escolher o melhor do que era bom e o ótimo do que era melhor, além de notar modos, ares maneiras, traços e fantasias dos pintores e dos escultores; investigando, dando a conhecer as causas e as raízes das maneiras e da melhoria e da piora das artes que ocorreram em diversos tempos e em diferentes pessoas. Vasari, em vez de se entrincheirar por trás de uma objetividade neutra, reivindica o direito de julgar a partir do seu próprio ponto de vista, segundo sua própria escala de valores (Vasari, 2011, p.XII).

Ademais, para os defensores da iniciativa vasariana como uma espécie de façanha de peso histórico, salienta-se que ao longo de muito tempo os textos de "Le Vite" serviram como a principal fonte de consulta para a compreensão da arte italiana em sua época áurea, qual seja, a passagem do gótico para o humanismo renascentista clássico e, por sua vez, deste último para o maneirismo. É em razão de "Le Vite" servir como obra basilar de consulta para as gerações futuras, ademais, que os defensores de Vasari ressaltam a sua forte presença em todo escrito moderno ou contemporâneo sobre aquele período histórico.

É por meio dos exemplos vasarianos, por sinal, que estudos modernos do conceito de arte clássica, como a obra homônima de Heinrich Wölfflin, na qual se defende que o termo Renascimento é impreciso e sem elevada correlação histórica com a Itália do Cinquecento, que se encontram os elementos para justificar a defesa de que a "arte clássica nada mais seja do que a continuação natural do Quattrocento, além de uma manifestação totalmente livre do povo italiano", posto que, para Wölfflin, "suas origens não estão na imitação de um modelo alienígena - a Antiguidade - e tampouco ela é o produto de uma escola, e sim fruto nascido em campo aberto, no momento de sua maior pujança" (1990, p.3). Do mesmo modo, parcela significativa dos estudos contemporâneos da arte italiana do período renascentista, a exemplo das proposições conflitantes da história social da arte e da história cultural da arte, respectivamente por Arnold Hauser e Ernst Gombrich, ambas encontram em Vasari os alicerces para a compreensão daquele mundo. Tal como nos observa Previtali, é historicamente 
reconhecível que "há cem ou talvez cinquenta anos, qualquer pessoa que se interessasse pela arte italiana, quer se tratasse de amador, historiador ou artista, tinha as Vidas de Vasari como livro de cabeceira" (Vasari, 2011, p.XI).

No que diz respeito ao segundo grupo, formada pelos críticos à obra "Le Vite", destacase o argumento de que Vasari, ao tornar presente em seus escritos os próprios juízos acerca dos engenhos criativos, e não estabelecer uma delimitação objetiva e imparcial para a sua narrativa, muitas vezes dificulta uma interpretação objetiva da arte do Renascimento por parte do leitor. Isto porque ao reiteradamente se valer da sua própria compreensão de mundo e suas escolhas, Vasari por vezes transparece em seus textos aspectos institucionais oficiais em sobreposição à relevância das obras, enquanto noutras tendencia a escolha dos artistas ao ambiente florentino, dando a entender que Florença fosse a responsável por todas as principais conquistas a arte do Renascimento em detrimento de Bolonha ou Veneza, e, por fim, de que em certos momentos Vasari fornece pouca atenção à exatidão de lugares e datas, tendo em vista que grande parte de suas informações descritas na obra provieram não de documentos, mas principalmente do testemunho de artistas que lhe eram contemporâneos.

Obviamente, apesar da relevância das considerações críticas ao texto de Vasari, temos de considerar que elas não são de todo válidas. Afinal, em se tratando de uma primeira tentativa de construir uma narrativa de caráter histórico sobre a arte, é bastante plausível considerarmos como legítimo - embora impreciso - que seu autor não detivesse a argúcia de recorrer à objetividade dos documentos, mas à memória e à veracidade dos testemunhos de seus contemporâneos. Por sua vez, vivenciando acima de tudo o universo cultural de Florença, e reconhecendo o valor do engenho e obras de seus artistas, é bastante plausível considerarmos como legítimo que em uma era de tecnologias primitivas para o transporte que um historiador vivendo em Florença desse preponderante destaque aos artistas da região em que habitava ${ }^{3}$. E, por fim, tendo em vista que à época de Vasari o trabalho artístico em sua significação corrente consistia na maioria das vezes em um tipo de ofício similar a outros ofícios, no sentido em que a funcionalidade, a economia e a rapidez de execução tinham preponderância sobre o qualitativo da obra para a justificação de um ordenado, consequentemente também os juízos do autor se pautavam sob os alicerces constitutivos dessa prática. É bastante plausível compreender, nesse sentido, os motivos pelos quais Vasari tenha se preocupado em demasia com os aspectos

\footnotetext{
${ }^{3}$ N.a.: cabe notar que apesar da tendência a certo 'bairrismo' florentino do escrito vasariano de 1550 , que esse juízo crítico foi aceito pelo próprio autor, tendo em vista que na revisão posterior de "Le Vite", de 1569, houve o acréscimo de relevantes artistas de Veneza, por exemplo.
} 
institucionais e com os contratos entre os artistas e seus mecenas, posto que se tratava de uma preocupação comum a todos os artistas da época.

Independentemente da apreensão valorativa referente aos rigores de "Le Vite", é admissível considerarmos que a despeito das críticas ao texto de Vasari que ele seja considerado um clássico dos estudos em arte, e por dois motivos de relevância: inaugurar uma narrativa historiográfica no campo das artes e, por conseguinte, servir como uma das fontes basilares para a compreensão da história da arte italiana no Renascimento. Contudo, somado a esses fatores, obviamente, está em questão para as novas gerações o pouco peso histórico que o texto de Vasari representaria para o estudo da arte como um todo. Afinal, apesar de por um longo período histórico "Le Vite" ter contribuído para uma compreensão paradigmática do fazer artístico, e pela óbvia razão da importância representada pelos artistas do Renascimento para uma formação em arte, por outro, com o advento das artes moderna e contemporânea, e o distanciamento dessas artes em relação às tendências representativas, consequentemente também aqueles escritos de Vasari caíram em certo desuso. Cabe, nesse sentido, perguntarmos: qual o real peso de "Le Vite" para a história e as teorias das artes? Em que sentido aquela obra inaugural, destinada a biografar os renomados artistas de um período áureo da arte, podem contribuir para as reflexões teóricas sobre a arte como um todo? Ou, diferentemente, "Le Vite" estaria delimitada a uma mera interpretação artefatual e histórica?

A seguir, demonstraremos que "Le Vite", apesar de olvidada por muitos estudos teóricos da arte das últimas décadas, consiste uma obra elementar para a própria compreensão e significação do conceito de arte e de sua prática. Em uma primeira etapa, observaremos como as transformações decorrentes do modernismo e da contemporaneidade artística, apesar de por um lado afastarem-se das formulações representativas e tradicionais da arte, por outro lado tornaram emergente a necessidade de uma definição da arte que abrangesse essa complexidade e sua historicidade. A seguir, em uma segunda etapa, observaremos como uma das principais definições filosóficas da arte em nosso tempo, o essencialismo histórico de Arthur Danto, encontrou no texto vasariano os alicerces para a instituição do conceito de era histórica da arte. Em terceiro lugar, por fim, defenderemos por que razões o emprego daquela obra de história da arte para a nossa compreensão do conceito de arte na modernidade não incorre em uma espécie de anacronismo, mas no encontro dos alicerces fundantes de nosso entendimento do conceito e da prática artística. 


\section{Artes moderna e contemporânea e a emergência por uma definição filosófica da arte}

As transformações pelas quais as artes vem passando desde a segunda metade do século XIX, com o advento do modernismo representado por movimentos como pontilhismo, art noveau, simbolismo, fauvismo, cubismo, expressionismo, futurismo, raionismo, construtivismo, abstracionismo, dadaísmo e surrealismo tornaram os fundamentos e os limites da criação artística objeto de debate não apenas artístico, mas também social e político. Intitulados de vanguardas artísticas, a pluralidade daqueles movimentos estilísticos, ao operarem um conjunto de mudanças na perspectiva do fazer artístico distanciaram a criação em arte de uma mera representação da realidade figurativa ou de uma idealização pautada nos métodos da representação realista, e passaram a questionar os princípios e métodos de composição até então institucionalizados. Eram esses princípios e métodos que compunham a matriz responsável pela formação do gosto comum e socialmente aceito pelo público, bem como por uma compreensão em certa medida unitária do processo artístico: se ao longo dos séculos emergiram diversos estilos artísticos e polêmicas estilísticas, em todo caso tratavam-se de contendas por fatores de ordem temática ou de pormenores técnico-estilísticos, posto que de todo modo a prática artística até então se pautara no imperativo da representação.

As transformações realizadas pelos movimentos vanguardistas do fim do século XIX e início do século XX, entretanto, estabeleceram uma tensão que ia muito além dos objetos adotados como motivos e dos pormenores técnicos, para interrogarem o próprio objeto e função da arte. Não estava mais em questão, por exemplo, questionar se os temas artísticos deveriam se pautar em representações de personagens nobres versus populares ou paisagens naturais versus urbanas, mas se a arte deveria de qualquer modo ter como sua função representar. Dito de outra maneira, aqueles movimentos apresentavam soluções criativas que questionavam a própria essência da arte, exigindo das instituições artísticas, do mercado e do público em geral uma reformulação de seus próprios conceitos de arte, posto que esta poderia ser encontrada em elementos subjetivos da vontade do artista, na sua expressão manifesta, na composição plástica, etc. Não é por outra razão, por sinal, que parcela significativa de artistas daquele período se ocuparam em conceber manifestos em defesa de seus movimentos, e a redigir teorias da arte nas quais formulavam e justificavam os preceitos de suas criações inovadoras.

Do mesmo modo, em contraponto, é pelo fato de as vanguardas terem colocado em questão os princípios da arte tradicionalmente institucionalizada que a tais movimentos decorreu uma forte reação institucional negativa das academias de belas artes, de artistas tradicionais que julgaram aquelas artes como modas passageiras, de discursos e manifestações 
políticas em regimes democráticos sentenciando a 'feiura' e a 'desumanização' daquelas produções, ou ainda, que em regimes políticos totalitários como o nazismo e o comunismo se deu a sentença de que tais manifestações artísticas eram fruto da degeneração e da decadência burguesa, sendo portanto condenadas à perseguição e proibição política ${ }^{4}$.

Em detrimento às sentenças críticas contra a chamada arte moderna das vanguardas, a revolução tecnológica emergente nas décadas de 1930 a 1960 mais tenderam a colaborar com essas novas manifestações artísticas do que em favor de seus críticos e da tese de que as vanguardas se restringiriam apenas a uma moda passageira no campo das artes. Além do mais, o modo como muitos desses artistas foram perseguidos pelos regimes nazista e stalinista justificaram para o período subsequente à Segunda Guerra um caráter heroico para aqueles criadores, institucionalizando-os como celebridades e símbolos de uma geração libertária, a exemplo de personalidades como Pablo Picasso, Jean Cocteau, Henri Matisse, Marc Chagall, Igor Stravinsky, Ernest Hemingway, Salvador Dali e Piet Mondrian.

É nesse contexto de afirmação da individualidade e em defesa do espírito criador do indivíduo que a arte decorrente às vanguardas, na segunda metade do século XX, não apenas ignorou a defesa de uma retomada tradicionalista da arte, como por sua vez radicalizou os princípios, os meios e as finalidades criativas da poética artística das vanguardas do início do século XX, estabelecendo o pluralismo e a liberdade criativa como paradigma da arte dos dias atuais.

Cunhada principalmente com o termo arte contemporânea, as manifestações artísticas a partir da contracultura dos anos 1960 diferem dos movimentos de vanguarda modernista por um conjunto de fatores. Por exemplo, ao expandirem os meios e suportes da criação artística para todo e qualquer objeto passível de uma interpretação poética ou conceitual da ordem da linguagem artística; ao ignorarem a formação clássica do domínio técnico do desenho, da pintura e da escultura; ao sobreporem a ideia-da-obra sobre o fazer-a-obra como papel elementar do artista, permitindo-lhes atribuir a si próprios a propriedade criativa de obras nas quais não tenha havido qualquer presença material de suas atuações; ao proporem a superação

\footnotetext{
${ }^{4}$ N.a.: para uma compreensão mais aprofundada dos embates políticos entre a arte moderna e regimes políticos democráticos e ditatoriais do século XX, sugerimos a leitura do capítulo "Arte e Política", na obra "Teorias da arte moderna", organizada por Herschel Chipp. A obra reúne textos e discursos de personalidades emblemáticas da política da primeira metade do século XX, como o político revolucionário russo Leon Trotsky, o senador estadunidense George Dondero, o historiador da arte stalinista Vladimir Kemenov e o líder nazista Adolf Hitler. A despeito das clarividentes diferenças ideológicas desses personagens, seus discursos sobre a arte moderna revelam um traço comum a todos: a concepção de que eram sintomas de uma espécie de decadência e de que deveriam ser prontamente rechaçadas em nome dos princípios artísticos tradicionais (Cf. CHIPP, 1988, pp.463508).
} 
do dilema que diferencia arte erudita e arte popular, institucionalizando ambas como sendo próprias do mesmo campo da arte, etc.

Movimentos como arte pop, neorrealismo, arte conceitual, minimalismo, concretismo, arte ótica, land art, tropicalismo, novo expressionismo, body art, arte digital e bioarte expandiram o horizonte de possibilidades criativas da arte para o diálogo com toda e qualquer forma de atuação, técnica ou expressão, estabelecendo um caráter libertário de realizações criativas que seria inimaginável para a arte tradicional representativa ou mesmo para a arte moderna, cujos questionamentos fundamentaram as bases e possibilidades criativas contemporâneas. A arte contemporânea, nesse sentido, manifesta-se não apenas como a consolidação do empenho transformador das artes adotado pelos primeiros artistas modernos, mas o dinamiza de maneira radical e o liberta de toda e qualquer dependência para com os alicerces tradicionais do fazer artístico que antecedem a essa era de transformações.

Entretanto, se a adoção do conceito de plena liberdade criativa se tornou bastante aceito entre artistas contemporâneos, e se em resposta a essa perspectiva os meios institucionais da arte, como galerias, museus, faculdades de arte, etc., se pronunciam em defesa e em articulada participação com os artistas contemporâneos, o mesmo não ocorreu com parcela significativa do público. Para este, em grande parte, o estranhamento propiciado pelas obras de arte contemporânea (estranhamento este que, por sinal, é desejado pelos artistas ao realizarem suas criações), muitas vezes exige de espectadores uma sensibilidade estética e intelectual apurados, uma abertura para a poetização de elementos que lhes são artisticamente exóticos, estabelecendo uma espécie de dialética entre artistas contemporâneos e público fundamentada na pergunta elementar da arte contemporânea: “mas isto é arte?”.

A pergunta “isto é arte?" é característica da arte contemporânea desde o seu advento nos anos 1960, e perdura até o presente nas exposições de arte contemporânea de nossos dias. Tratase de um sintoma característico e representativo do papel da arte contemporânea em sua relação com aquilo o que comumente se compreende como obra de arte, advindo das analogias que se possa fazer entre tais produções contemporâneas e as tradicionais obras presentes nos manuais de história da arte. Afinal, é em razão do estranhamento do espectador diante uma obra contemporânea, cuja tentativa de entendimento o leva à procura de algum tipo de analogia com as obras de arte tradicionais (obras estas fundamentadas e formadoras de sua compreensão do termo obra de arte), que a pergunta “isto é arte?” emerge ao seu questionamento. Tal interrogação, ao contrário do que muitas vezes se possa vir a pensar, não corresponde a pergunta valorativa, nem tampouco de um juízo taxativo: trata-se de uma interrogação notadamente 
comparativa, que busca compreender o que torna aquele objeto arte se ele é tão distinto de tudo aquilo que aquela pessoa aprendeu ser arte, seja na forma do objeto, no seu feitio, no papel e talento do artista, etc. Afinal, para citarmos um exemplo, a característica diferença entre uma obra contemporânea como “Equilibrium”, de Jeff Koons (Fig.1), que consiste em uma bola de basquete em perfeito equilíbrio, no centro de um tanque de vidro cheio de água misturada com reagente de cloreto de sódio, e uma obra e mais tradicional para a história da arte, como a pintura em óleo sobre tela intitulada "Forja de Vulcano", de Diego Velázquez (Fig.2), quando colocadas sob um mesmo tipo de caracterização que faz delas unidades de um mesmo conjunto chamado arte, necessariamente nos conduz a um questionamento que não é em princípio de valor (já que, afinal, sob um prisma da criatividade pode-se justificar que a solução química encontrada por Koons ao mergulhar e estabilizar uma bola cheia de ar em um tanque de água consiste um achado), mas por que razão objetos tão distintos seriam tidos como entes de uma mesma espécie de coisas, às quais chamamos obras de arte?

Somando-se à arte moderna a arte contemporânea, observa-se que as transformações oriundas desta última acrescentam àquela um elemento de debate mais profundo, posto que a partir das transformações artísticas da segunda metade do século XX não se tem mais apenas o questionamento institucional, social e político acerca daquelas manifestações artísticas, mas a emergência da própria questão filosófica da definição da arte, isto é, a) de sabermos o que torna um objeto obra de arte (o que torna legítimo dizer se algo é ou não é uma obra de arte); b) de compreendermos de que modo a história da arte, em suas diferentes manifestações, encontra numa definição filosófica da arte um fundamento comum; e, por fim, c) de se encontrar numa definição filosófica o elo que permite caracterizar como objetos de uma mesma espécie chamadas obras de arte quando tais objetos são manifestações caracteristicamente distintas, como se dá no caso de uma obra contemporânea e uma obra clássica tradicional. 

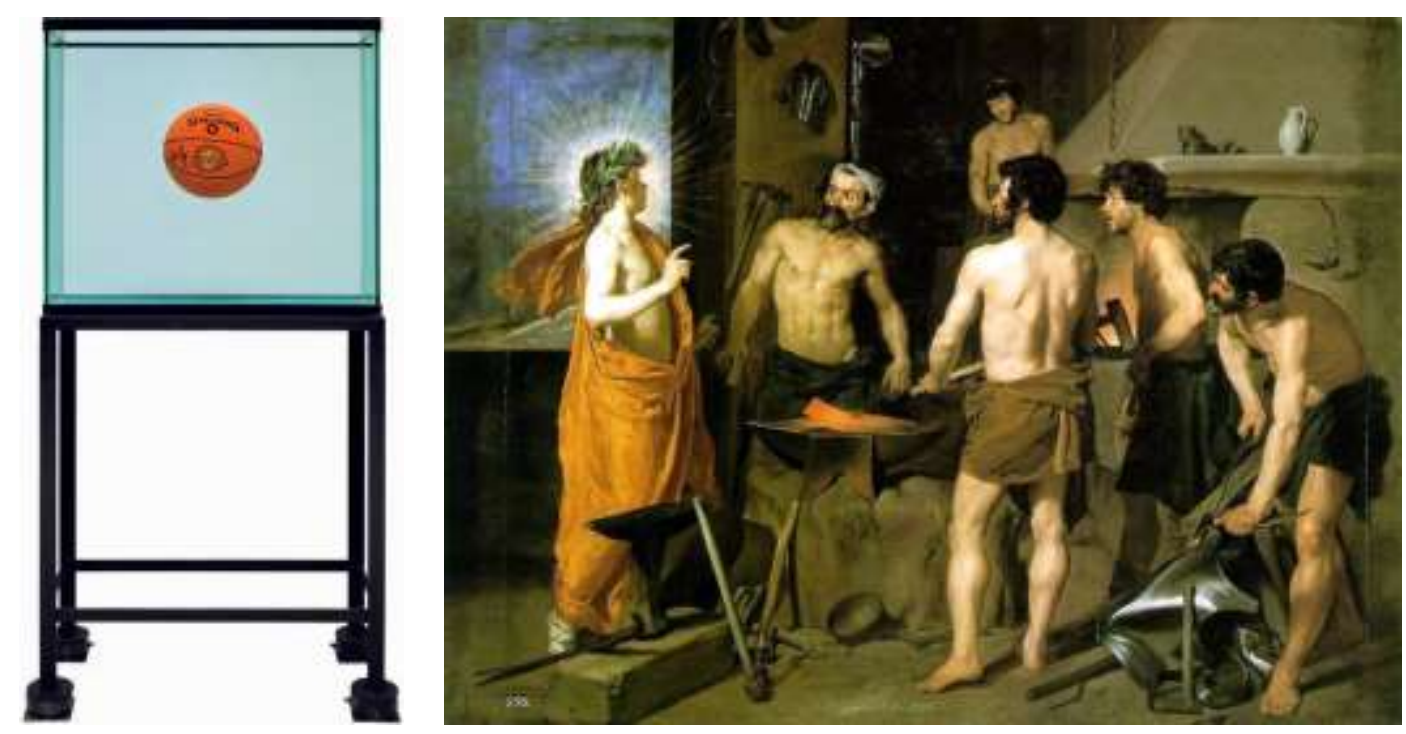

À esquerda, Fig.1, Jeff Koons, "Equilibrium” (vidro, aço, reagente de cloreto de sódio, água destilada e bola de basquete), 164,5x78,1x33,7cm, 1985. À direita, Fig.2, Diego Velázquez, “A forja de Vulcano” (óleo sobre tela), 223x290cm, 1630 .

Obviamente, tais interrogações carregam consigo um conjunto de consequências, e que dizem respeito não apenas à compreensão histórica do fenômeno artístico, mas também sobre o papel exercido por criações e teorias artísticas nesses diferentes estágios históricos, seja para a compreensão da arte como a totalidade de um conjunto que engloba esses paradigmas criativos tão distintos, ou para compreender o papel de um momento distinto da arte na totalidade do conjunto. Afinal, reconhecendo-se que manifestações artísticas tradicionais, modernas e contemporâneas são demasiadamente distintas entre si, mas por outro lado compreendendo que essas diferentes manifestações fazem parte de um mesmo conjunto a que chamamos arte, qual o papel das produções oriundas dessas diferentes manifestações para a compreensão do conjunto, da arte em sua totalidade? É em razão da necessidade de uma concepção de arte que englobe essa complexidade histórica e seus paradigmas que se manifesta a necessidade de uma definição filosófica da arte.

\section{O papel de Giorgio Vasari para a fundamentação do essencialismo histórico e da era da arte de Arthur Danto}

Ao reconhecermos o caráter emergente da questão filosófica da definição da arte a partir da segunda metade do século XX e em decorrência das transformações oriundas da arte moderna e da arte contemporânea para o entendimento filosófico, está em questão primeira o fato de que a partir dessas variações empíricas do âmbito de criação e recepção artística se dá o reconhecimento de que o fenômeno artístico é demasiado complexo, e que o problema da 
definição desse fenômeno e dessa complexidade se torna central para os filósofos da arte a partir do advento da arte moderna e da arte contemporânea ${ }^{5}$. Ademais, é por meio do reconhecimento dessa complexidade do fenômeno artístico e de suas transformações históricas que, no âmbito do debate filosófico, se torna emergente a reflexão sobre o papel da arte contemporânea e da arte moderna para a totalidade da arte e, também, do papel da arte tradicional para a compreensão dessa totalidade e suas transformações. É a partir de uma definição filosófica da arte, e em reconhecimento de sua complexidade histórica, que uma compreensão do que é arte legitima o entendimento dessa prática humana, de seus eventos históricos (incluindo o seu nascimento, desenvolvimento e narrativas), bem como, por fim, de que modo esse conceito abrange toda a sua diversidade histórica.

Uma primeira questão que rapidamente se apresenta em relação a essa necessidade de uma definição da arte é se ela é possível. Dito de outra maneira, dado o caráter tão distinto das manifestações históricas ao longo de sua história, e notadamente a partir das vanguardas artísticas do início do século XX e da arte contemporânea, seria possível encontrarmos uma definição legítima que englobe todas essas diferentes acepções do conceito de arte, apesar de todo o seu pluralismo? Para a corrente estética intitulada neowittgensteinianismo, formada pelos pensadores Paul Ziff, Morris Weitz e William Kennick na década de 1950, a proposição de um conceito definidor da arte está condenado à frustração, e tem por motivo o próprio caráter criativo das artes e sua pluralidade, o que exigiria igual abertura de seu conceito.

Segundo os neowittgensteinianos, o conceito de arte é aberto em razão da própria natureza criativa das artes. Segundo tal conjetura, ao se propor uma definição da arte, por exemplo, "arte é uma representação mimética", "arte é uma realização plástica de forma significante", "arte é uma realização plástica expressiva", ou qualquer outra tentativa definidora, todas elas incorreriam no equívoco de tentar restringir a um único conceito uma atividade plural, que pode englobar estas e tantas outras acepções para o fazer artístico que

\footnotetext{
${ }^{5}$ N.a.: Essa questão merece aqui um adendo. Ao postularmos que a preocupação filosófica com a definição da arte se torna emergente a partir da segunda metade do século XX e em razão das transformações oriundas do universo criativo das artes contemporâneas (em soma às já polêmicas mudanças operadas pela arte moderna), nosso argumento pode conduzir à equivocada interpretação de que a natureza da arte só teria se tornado uma questão filosófica naquele momento histórico e em decorrência das profundas mudanças artísticas oriundas daquele período. Nesse sentido, essa interpretação poderia objetar que neste artigo se estaria a desconsiderar a existência de teorias filosóficas da arte antecedentes à arte contemporânea, como a teoria da forma significante em Roger Fry ou a origem poética da arte em Martin Heidegger, ou mesmo concepções clássicas do conceito filosófico de arte, por exemplo, a mímesis em Platão e Aristóteles, tal como se essas concepções teóricas não tivessem postulado o problema do que é a arte em decorrência de não partilharem um mesmo entendimento do conceito de arte em nossos tempos, ou por thes faltarem as transformações factuais da história recente das artes. $\mathrm{O}$ meu argumento, entretanto, é diverso: com o advento de paradigmas artísticos demasiadamente inovadores na primeira e na segunda metade do século XX, a prática artística sofreu tamanho conjunto de mudanças que a reflexão filosófica de seu conceito se tornou basilar para a compreensão do que é a arte.
} 
viessem a surgir. Afinal, em se tratando de uma atividade amparada no processo criativo, toda e qualquer definição perderia a sua legitimidade tão $\operatorname{logo}$ as manifestações artísticas fundassem outras possibilidades criacionais. Nesse sentido, para essa corrente estética a própria tentativa de atribuir à arte uma definição constitui um equívoco, restando à reflexão sobre a arte tãosomente identificar as obras artísticas a partir de semelhanças familiares existentes entre as diferentes obras.

É com o pensador estadunidense Arthur Danto, entretanto, que a partir da década de 1960 - e em concomitância com os procedimentos artísticos daquele período - que a necessidade de uma definição filosófica da arte encontra uma correspondente teoria filosófica que possibilita compreender o fenômeno artístico em sua complexidade histórica e criativa. Ao visitar uma exposição do artista pop Andy Warhol, em 1964, Danto observou que uma das obras ali apresentadas, intitulada "Brillo Boxes" (Fig.3), respondia a um momento histórico tanto para a arte quanto para o pensamento filosófico sobre a arte.

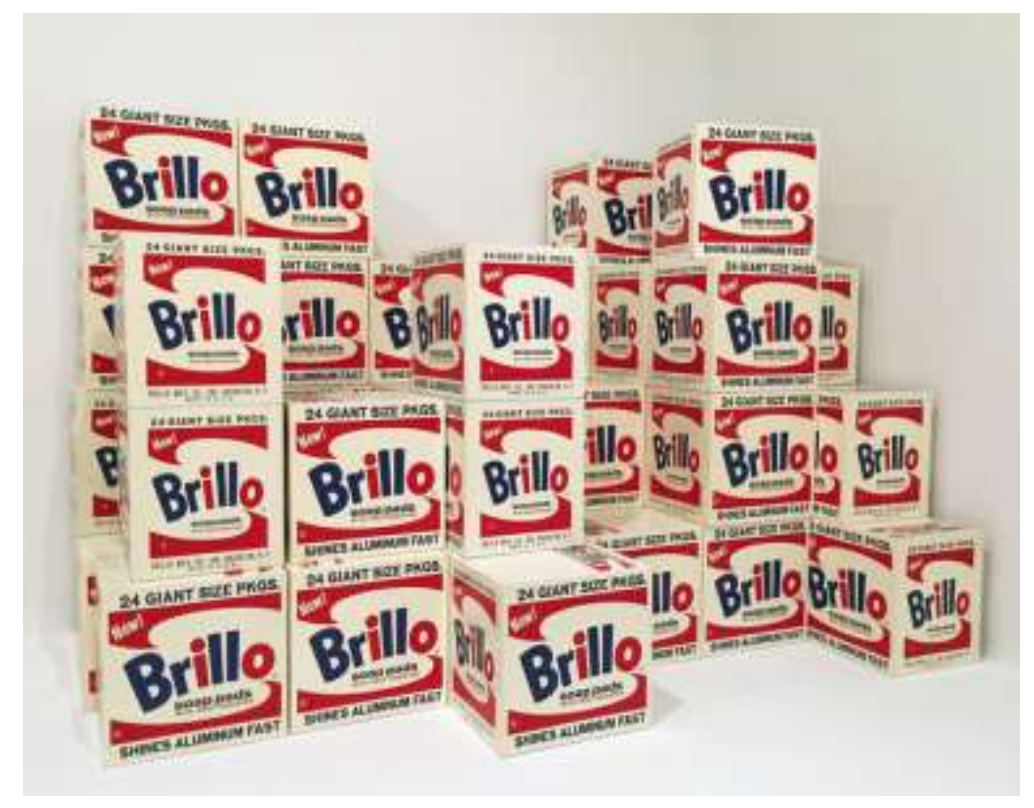

Fig.3: Andy Warhol, "Brillo Boxes", 1964. Pintura sobre compensado $(43,3 \times 43,2 \times 36,5 \mathrm{~cm}$ cada $)$

A obra "Brillo Boxes" é formada por um conjunto de caixas de compensado pintadas, fac-símiles das caixas de papelão de atacado das esponjas de aço da marca Brillo, dispostas na galeria de forma a remeterem ao ambiente comum de um depósito de supermercado. Ao observá-las, Danto percebeu que o cerne daquelas obras não se dava apenas no fato de seu autor conduzir ao ambiente da arte objetos similares aos do cotidiano, ou de o artista tensionar os paradigmas das Belas Artes ao designar por motivo artístico a representação de objetos funcionais fabricados em série. Tampouco lhe preocupava se o resultado daquelas caixas de 
compensado seriam uma boa ou uma má arte. Para o esteta de Ann Arbor, é a quase indiscernibilidade perceptiva daquelas obras de Warhol em relação às caixas de papelão de Brillo dos supermercados aquilo que responde pela sua importância artística e filosófica: aquela obra estabelece um dilema para teoria estética neowittgensteiniana das semelhanças de família existente entre as obras de arte, e ainda interroga o próprio ser-obra-de-arte das obras de arte em razão de sua indiscernibilidade perceptual frente aos objetos comuns.

A questão filosófica primordial engendrada por Warhol nas "Brillo Boxes", de acordo com Arthur Danto, e que veio a ser elementar para toda a sua filosofia da arte, encontra-se nesse argumento dos indiscerníveis: 'o que torna um objeto obra de arte quando esse objeto é indiscernível de um objeto comum?' (DANTO, 1964, p.580-581). Ora, o argumento neowittgensteiniano afirma que as obras de arte não possuem uma essência comum, sendo possível apenas identifica-las por meio das semelhanças comuns entre as obras de arte (já que as obras de arte seriam similares entre si e diferentes dos demais tipos de objetos). Tal argumento seria válido em relação à história da pintura, por exemplo, caso tomássemos por objeto de reflexão uma pintura abstrata, que tende a ser semelhante a outras pinturas abstratas, ou destas em relação a outras etapas da história da pintura vanguardista em que a deformação do caráter figurativo possibilita similaridades com as formas abstratas. Tal como as semelhanças de família são plausíveis se tomado o exemplo de obras figurativas do período das vanguardas, posto que elas também possuem elos de similaridade com as pinturas representacionais de outros períodos históricos da arte. Porém, não é este o caso apresentado pelas "Brillo Boxes". Para Danto, não estava no fato de as caixas terem sido pintadas o seu caráter artístico, até porque se tratavam de um fac-símile das caixas de Brillo cotidianas e cuja arte gráfica não fora objeto de criação de Warhol. Do mesmo modo, para o pensador de Ann Arbor, mesmo que Warhol tivesse apenas recolhido um conjunto de caixas de papelão nos supermercados e as distribuído pela galeria o mesmo problema filosófico se faria presente. $\mathrm{O}$ que estava em questão para Danto, é porque aquelas obras de Warhol seriam arte (tendo sido inclusive avaliadas e institucionalizadas como obras de arte) ao passo que as caixas de papelão de Brillo nos supermercados não receberiam o mesmo estatuto. $\mathrm{O}$ que legitimaria essa transfiguração? (Ibidem, p.581).

A resposta inovadora de Arthur Danto é a de que as "Brillo Boxes" traziam à tona o caráter complexo dos próprios objetos a que chamamos arte. Segundo o esteta estadunidense, a indiscernibilidade das "Brillo Boxes" e das caixas de Brillo nos supermercados denunciam que o ser-obra-de-arte difere do ser-objeto-comum não em razão dos elementos materiais de um e 
de outro, por exemplo, ser pintura ou ser impresso em série, ou dos atributos de ordem perceptiva das obras de arte, por exemplo, serem as "Brillo Boxes" perceptualmente indiscerníveis das caixas de Brillo de papelão, e sim porque as obras de arte trazem consigo um elemento a mais que não se encontra presente nos objetos comuns. Este algo, por sua vez, é uma atmosfera de teoria artística, ao que Danto chama mundo da arte (Ibidem, p.580).

Segundo o filósofo de Ann Arbor, a complexidade da obra de arte é da mesma ordem, por exemplo, aos de determinados objetos de outras práticas humanas. Consideramos que a água e a água benta sejam materialmente indiscerníveis e materialmente da mesma estrutura química, mas, por outro lado, reconhecemos que ambas fazem parte de mundos distintos e com valores distintos. Empregamos cotidianamente a água para a nossa hidratação, para lavar objetos, para tomarmos nossos banhos diários. No âmbito da prática religiosa católica, entretanto, a água benta não corresponde a um mero líquido que podemos empregar para a hidratação ou para lavar uma calçada. Apesar de ser idêntica à água comum, a água benta recebe uma significação de outra ordem, conduzindo-a a uma interpretação que a difere de toda outra água, embora entre elas não haja qualquer diferença de ordem física. $\mathrm{O}$ mesmo exemplo da significação simbólica da água benta também poderia ser aplicada a outras atividades, como as convenções econômicas, por exemplo, posto que não é a impressão da tinta sobre uma nota de dinheiro, ou a qualidade da impressão sobre aquele pedaço de papel o que responde pelo valor que atribuímos a uma nota de um ou dez dólares.

No que diz respeito ao campo das artes, as "Brillo Boxes" de Warhol conduzem Arthur Danto à apreensão filosófica de que aquilo o que torna um objeto obra de arte é a atribuição de um caráter identificatório próprio, artístico, alicerçado sobre um objeto. Atribuída a significação, o objeto é transfigurado para um outro sentido. Desta forma, para Danto, é a metáfora de significação artística que ocorre quando se atribui a um objeto como um mictório o título "Fonte", como no ready-made de Marcel Duchamp, ou quando se aponta o dedo para uma forma constituída por poucos borrões de tinta sobre uma tela. e se diz 'este é Ícaro', a exemplo da pintura "A queda de Ícaro", de Bruegel, que se dá a constitutividade de um objeto como obra de arte (seja este objeto uma pintura realizada pelo artista ou um objeto cotidiano recolhido aleatoriamente e sobre o qual se atribua uma constitutividade artística que passa a distinguir esse objeto de outros perceptualmente iguais) (Ibidem, p.576).

Sendo a presença de uma atmosfera artística aquilo o que torna um objeto obra de arte, isto é, o ato de aplicar sobre um objeto uma constitutividade que o desloca dos objetos comuns para o mundo da arte, Danto observa que a sua constatação oriunda das "Brillo Boxes" de 
Warhol incidem em uma definição essencialista da arte, qual seja, a fórmula de que uma obra de arte é constituída por um objeto sobre o qual se corporifica um significado (e, notadamente, um significado que o torna partícipe do mesmo mundo das demais obras de arte) (DANTO, 1997, p.195-196). Desta forma, sua teoria considera que perante uma obra de arte contemporânea, ou uma peça de arte moderna, ou uma pintura representacional clássica, em todos esses casos encontramos na corporificação de uma significação artística sobre seus objetos o elo que nos permite, de modo legítimo, atribuirmos a cada um deles o mesmo termo arte (Idem). Consequentemente, e a despeito de todas as suas diferenças materiais e perceptivas, é a presença do significado artístico sobre os objetos o que nos permite interpretar "Equilibrium" de Jeff Koons, "A forja de Vulcano", de Velázquez, e "Brillo Boxes", de Andy Warhol, como sendo partes de um mesmo mundo da arte.

A concepção filosófica da arte de Danto, entretanto, não se restringe apenas a atribuir ao conceito de arte uma definição. Tendo em vista que o seu conceito de mundo da arte implica uma fórmula que abrange desde a arte representativa tradicional, o modernismo e as artes contemporâneas, o pensador de Ann Arbor identifica nessas transformações artísticas ao longo da história não um processo de criatividade aleatório e sem correspondência uns com os outros, mas um processo de desenvolvimento.

Danto afirma que a sua filosofia da arte corresponde a um duplo processo, ao mesmo tempo essencialista e histórico. Apesar da aparente contradição em se pensar que algo possa ao mesmo tempo se encontrar condicionado à historicidade e, por outro, ser essencialista (isto é, ser independente da história), o pensador estadunidense observa que tal contradição é apenas aparente. Sua concepção da arte é essencialista apenas em um sentido intensional, isto é, no que diz respeito à fórmula de definição da arte. Afinal, se é obra de arte a corporificação do significado sobre o objeto, todo objeto que receba essa corporificação de significado será arte, independentemente das condições históricas nas quais esse objeto se presentificar. Por outro lado, destaca-se que sendo as obras de arte realizadas ao longo da história (isto é, nos respectivos momentos históricos em que seus artistas as realizam), a arte também é extensional, consequentemente a arte se faz também histórica no sentido em que o conceito de corporificação do significado se faz presente em toda obra de arte cuja manifestação ocorre historicamente. Logo, a arte é essencialista no sentido de que para ser arte um objeto depende da corporificação do significado, e, por outro, é histórica porque o conjunto das obras de arte existentes correspondem à manifestação histórica da corporificação do significado no momento histórico de cada obra (Ibidem, p.28-29). 
A concepção dantiana do essencialismo histórico diz respeito, portanto, tanto à definição de arte como às manifestações da arte ao longo da história. E, sendo a arte uma prática que envolve um processo de realizações, crises, questionamentos e embates teóricos, Danto diagnostica que esse desenvolvimento histórico decorre de um processo de ordem teleológica. Para o pensador de Ann Arbor, as "Brillo Boxes" de Warhol não representam um passo revolucionário das artes apenas por terem conduzido o pensador à formulação de uma definição da arte. Antes, está em jogo para Danto que aquela obra de Andy Warhol responde ela própria a um processo de desenvolvimento histórico dentro do mundo da arte de reflexões sobre o próprio fazer artístico (Ibidem, p.36). Dito de outra maneira, ao propor como obra de arte um objeto perceptualmente indiscernível de um objeto comum, e tendo sido esse objeto interpretado como obra de arte pelos meios institucionais e seu público conhecedor da arte, o próprio mundo da arte teria chegado a uma etapa de autoconsciência filosófica, visto que aquele artista, a galeria que o exibiu e os críticos que validaram aquele objeto como obra de arte haviam compreendido que não era nos fatores materiais da arte, ou na recepção perceptiva que aqueles objetos compunham, mas na corporificação de um significado artístico sobre um objeto que se dava a consumação constitutiva de algo como obra de arte (Idem).

Ademais, para Danto, não foi por ordem do acaso que aquele meio social conhecedor da arte institucionalizou e compreendeu a artisticidade da proposição de Warhol. Marcel Duchamp, por exemplo, propôs em 1917 a exposição de um mictório ao qual intitulara "Fonte" em uma exposição de artistas de vanguarda. Apesar de a proposição ter sido feita para um meio libertária, a obra foi rejeitada e, posteriormente, ao ser discutida pelo meio artístico foi sempre ou em razão da atitude de Duchamp ou em vista da procura de formas estéticas esculturais naquele mictório manufaturado. Diferentemente, com a obra de Andy Warhol, não apenas a aceitação do objeto como artístico foi instantânea, como as interrogações decorrentes em relação ao objeto se deram em torno de qual característica aquela obra possuiria a ponto de distingui-la dos objetos comuns (DANTO, 2000, p.09).

Para o essencialismo histórico de Danto, nesse sentido, a "Brillo Boxes" de Warhol constitui o resultado final de uma longa etapa de desenvolvimento histórico da arte rumo à sua autoconsciência filosófica, algo que só se tornou possível em razão de anteriormente a essa etapa ter ocorrido uma espécie de etapa histórica de crise, representada pelo modernismo, seus manifestos e as diferentes proposições definidoras da arte enquanto forma expressiva, forma significante, etc., e, obviamente, pela preexistência de uma etapa histórica na qual se compreendia e se procurou desenvolver a ideia e as técnicas de que o papel da arte consistiria 
em representar mimeticamente a realidade, seja a partir de motivos idealistas ou realistas, etapa esta que inaugura a narrativa histórica da arte (DANTO, 1997, p.36-37).

Embora os estudos sobre o essencialismo histórico dantiano procurem se concentrar primordialmente nas etapas moderna (intitulada era dos manifestos) e contemporânea (intitulada era pós-histórica) da arte, e na chegada da arte a uma autoconsciência filosófica por meio das "Brillo Boxes", de Andy Warhol ${ }^{6}$, é na primeira etapa do desenvolvimento histórico da arte, qual seja, do desenvolvimento de sua primeira narrativa, que Arthur Danto encontra um dos cernes para a justificação do aspecto histórico de sua teoria essencialista. É nesse estágio, por sua vez, que encontramos o papel elementar do "Le Vite" de Giorgio Vasari, para a compreensão do advento da era histórica da arte no pensamento dantiano.

Em Danto, o primeiro estágio histórico da arte corresponde à busca pelo desenvolvimento mimético nas representações. Em razão da reminiscência ao caráter mimético das obras como objeto próprio da arte, podemos nos ver tentados a crer que Danto projetasse nos escritos platônicos sobre a arte como mímesis o início histórico da arte, ou, em similaridade à interpretação artefatual dos escritos comuns de história da arte, cujo horizonte descritivo apresenta o início da arte como sendo os primeiros artefatos de pinturas e esculturas rupestres. Tal perspectiva, obviamente, nos levaria a crer que para Danto essa narrativa desenvolvimentista encontraria na antiguidade clássica e helenística, ou no desenvolvimento da representação renascentista, maneirista, barroca e romântica os períodos áureos da primeira narrativa histórica da arte, e nos artefatos pré-históricos o início histórico da arte.

Entretanto, a teoria dantiana do mundo da arte não engloba todo e qualquer artefato (seja este pintura, escultura ou denotativo de outras de nossas práticas artísticas comuns) como sendo propriamente um objeto artístico. E a razão de Danto não é, de qualquer modo, infundada. Tal como vimos anteriormente, para o pensador de Ann Arbor aquilo que torna um objeto obra de arte é a corporificação de significado (obviamente, de significado artístico) sobre um objeto. Consequentemente, para que um objeto possa vir a ser arte, em qualquer momento histórico, é necessário que a significação corporificada sobre aquele objeto seja propriamente a

\footnotetext{
${ }^{6}$ N.a.: Danto concebe que os movimentos artísticos dos anos 1960 respondem a uma chegada de autoconsciência filosófica, representada primordialmente pelas "Brillo Boxes" de Andy Warhol. Tal momento, para o pensador estadunidense, constitui uma chegada ao fim da arte, não no sentido do acabamento da prática artística, e sim de que compreendida a essência teórica da prática artística (e sua não delimitação aos paradigmas narrativos da mímesis, da expressão, da forma significante, dentre outros) consequentemente aos artistas estaria permitida a plena liberdade para toda forma de proposição no campo das artes, ao passo que a nenhum objeto proposto como artístico passa a ser legitimamente possível a negação desse estatuto. Nessa nova etapa, intitulada por Danto de arte pós-histórica, o campo das artes se encontra liberto para a prática radical do pluralismo estilístico e do multiculturalismo, não podendo a arte ser condicionada a qualquer narrativa excludente. Neste artigo, entretanto, não me ocuparei em qualquer medida do debate desse último estágio histórico da arte.
} 
corporificação de ordem artística, e não outra. Ora, é bastante plausível à nossa compreensão e por diversas concepções teóricas da arte - que as pinturas e as esculturas pré-históricas, antigas e medievais eram realizadas com objetivos de ordem votiva, como os ícones religiosos nas igrejas medievais, as pinturas e esculturas nos santuários gregos antigos, as estátuas de imperadores romanos perante as quais os súditos compreendiam a afirmação do poder do líder supremo, tendo de se curvar a elas, dentre outras, não tiveram em suas realizações e exposições qualquer tipo de vínculo da ordem da apreciação estética, ou para fruições da sensibilidade lúdica, ou para a reflexões metafóricas, etc. Tanto quanto os textos platônicos sobre a arte não tratavam da arte no sentido que o termo é compreendo hoje, mas como techne. Que aqueles artefatos pré-históricos, antigos e medievais tenham sido pintados ou esculpidos com maestria, é algo que decorreu da busca e exigência pela excelente realização, mas de modo algum para o preenchimento de fins de ordem estética ou para a contemplação lúdica e metafórica. Ademais, mesmo que para aquelas culturas da pré-história, antiguidade e medievo tenha existido alguma obscura preceituação de ordem puramente contemplativa em sentido artístico, nada temos de registros dessas atividades ou da existência de suas instituições, ou, em outras palavras, parece improvável que aquelas culturas tenham consumado alguma prática da arte tal como o termo é atualmente compreendido. Em contraste, por outro lado, temos demasiadas documentações acerca das funções sociais, educativas e religiosas daqueles artefatos.

Consequentemente, para o essencialismo histórico de Danto não faria qualquer sentido a compreensão como obra de arte de objetos sobre os quais não tenha sido engendrada qualquer corporificação de significado artístico. Que na era moderna tenhamos o hábito de atribuir àqueles artefatos da antiguidade e do medievo uma contemplação de ordem artística, e muitas vezes decorrente do virtuosismo com que aquelas obras antigas e medievais foram feitas, esse modo de interpretação é tão-somente nosso, e diz não sobre a artisticidade daqueles feitos ou daquela época, mas do modo como nós, em nossa era, já afastados historicamente daquelas culturas, de seus hábitos e de suas crenças, tendemos a considerar aqueles objetos em nossos dias apenas e tão-somente sob a mesma perspectiva artística que também empregamos para apreciar as obras de arte criadas em nosso tempo e projetadas para o tipo de apreciação artística próprios do nosso tempo. Para haver corporificação de significado artístico sobre um objeto, consequentemente, é necessário que à época de sua criação e exposição do objeto exista a prática da arte e o entendimento artístico de objetos: a arte só existe em uma era da arte.

Para Danto, é no "Le Vite", de Vasari, que podemos demarcar um início histórico da arte na acepção que hoje damos ao termo. Recorrendo a uma análise de Hans BELTING (2012, 
p.215) sobre a transição histórica das imagens devotas para as criações artísticas, na qual o historiador da arte alemão afirma ter encontrado no proêmio da segunda parte de "Le Vite" uma pretensão vasariana de separar o objeto de seu escrito da herança histórica da produção dos artefatos como um mero tipo de ofício, Danto identifica naquele momento histórico a imputação de uma espécie de corporificação do significado (da arte) sobre os objetos, dada que aquela transição demarcaria um distanciamento de Vasari em relação à prática do antigo modo com o qual o ofício dos artistas era interpretada. Diz o texto vasariano, na edição de 1550:

Quando [...] comecei a descrever estas vidas, não era minha intenção fazer uma nota sobre os artistas ou algum inventário de suas obras; também nunca julguei que fosse finalidade digna deste meu trabalho demorado e árduo - apesar de belíssimo descobrir números, nomes e locais de origem, bem como indicar em que cidade e em que lugar exato é possível encontrar agora pinturas, esculturas ou construções; porque isso eu poderia fazer com uma simples tabela, sem inserir em lugar nenhum os meus juízos a respeito. [...] assim, empenhei-me não só em dizer o que fizeram os artistas, como também em selecionar, para comentar, o que há de melhor naquilo que é bom, e o que é ótimo no que há de melhor, observando cuidadosamente técnicas, expressões, estilos, traços e inventividade de pintores e escultores, tentando, com a maior diligência que pude, mostrar àqueles que tais coisas não sabem fazer por si sós as causas e as raízes dos estilos, bem como das melhorias ou pioras introduzidas nas artes, coisas que ocorreram em diversos tempos e em diferentes pessoas (Vasari, 2011, p.169) ${ }^{7}$.

Em contraposição à análise de Belting (e adotada por Danto em sua teoria da era da arte), que encontra no texto vasariano o advento da arte como esquema narrativo, fazendo emergir um novo entendimento para o conceito de arte diverso ao do ofício medieval dos artífices, poderíamos objetar que a obra do aretino não possui por objeto uma história da arte no mesmo sentido que o nosso, já que à época de Vasari não havia uma prática institucional da arte como objeto de fruição, nem críticos dessa arte ou museus especializados nessa arte. De fato, tal objeção encontra escopo não apenas na inexistência àquela época da consititutividade institucionalizada da arte de nosso tempo, como, ainda, o próprio termo empregado por Vasari para se referir aos artistas nos leva a denotar essa interpretação. Como podemos observar na

\footnotetext{
${ }^{7}$ Cf. (Vasari, 1986, p.106): “Quando io presi primieramente [...] a descrivere queste vite, $e^{\prime}$ non fu mia intenzione fare una nota delli artefici et uno inventario, dirò cosí, delle opere loro, né giudicai mai degno fine di queste mie, non so come belle, certo lunghe e fastidiose fatiche, ritrovare il numero et i nomi e le patrie loro, et insegnare in che città et in che luogo appunto di esse si trovassino al presente le loro pitture o sculture o fabriche; che questo io lo arei potuto fare con una semplice tavola, senza interporre in parte alcuna il giudizio mio [...] Per la qual cosa avendo io preso a scriver la istoria de' nobilissimi artefici, per giovar all'arti quanto patiscono le forze mie, et appresso per onorarle, ho tenuto quanto io poteva, ad imitazione di cosí valenti uomini, il medesimo modo; e mi sono ingegnato non solo di dire quel che hanno fatto, ma di scegliere ancora discorrendo il meglio da 'l buono, e l'ottimo da 'l migliore, e notare un poco diligentemente i modi, le arie, le maniere, i tratti e le fantasie de' pittori e degli scultori; investigando, quanto piú diligentemente ho saputo, di far conoscere a quegli che questo per se stessi non sanno fare, le cause e le radici delle maniere e del miglioramento e peggioramento delle arti, accaduto in diversi tempi et in diverse persone". Ressaltamos, ademais, que o mesmo texto, com muito poucas modificações estilísticas - mas não do conteúdo apresentado - também se encontra no Proêmio da Segunda Parte de "Le Vite" na edição de 1569 (Cf. VASARI, 1997, pp.518-519).
} 
nota de rodapé n.7, deste artigo, e em contraposição à tradução para a língua portuguesa (bem como da maior parte das traduções do texto vasariano), ao se referir aos artistas, em "Le Vite", o aretino se vale do termo artefici ou da expressão nobilissimi artefici, designando portanto 'artesãos' ou 'artífices' e ‘os mais nobres artesãos'. O emprego da palavra artífice, neste caso, torna o significado do termo mais próximo à compreensão do ofício dos artífices medievos e antigos do que propriamente do artista criador, tendo maior relação com os termos latinos ars e artis, que embora sejam etimologicamente a matriz do nosso termo arte são, por outro lado, a tradução medieva referencial do termo grego techne.

Em contraposição ao fato de Vasari se valer do termo artefici para designar os artistas por ele biografados, entretanto, é no conteúdo descrito pelo autor no proêmio da segunda parte de "Le Vite" que se fundamenta o argumento de Belting adotado por Danto. Apesar do pressuposto emprego de um termo aplicado para um desígnio tradicional da antiguidade e do medievo, o texto de Vasari realiza uma espécie de transição de significado sobre a palavra e sua designação, enobrecendo aquele termo e atribuindo-lhe novas considerações em contraste à tradição, cujo trato relativo ao trabalho de pintores, escultores e arquitetos era o de três entre outras atividades do ofício manual ${ }^{8}$.

A passagem de Vasari, entretanto, demonstra uma mudança de perspectiva quando o autor aponta que ao dar início à sua empreitada de biografar os artistas (artefici), poderia ter optado por um modelo próprio à tarefa comumente devotada àquele tipo de trabalho, realizando um mero inventário de suas obras, ou indicar os locais onde seriam possíveis encontrar pinturas, esculturas e construções - o que, como o próprio aretino observa, demandaria tão-somente uma tabela. Diferentemente, Vasari enobrece a atividade daqueles artistas (artefici) por ele escolhidos como os mais nobres e, do mesmo modo, reconhece em sua atividade de biografálos uma atribuição cujos objetos são de tal importância que lhe exigem um empenho que não são o da ordem da enumeração quantitativa, mas do juízo crítico sobre a relevância de cada um, o que, consequentemente, demanda o empenho na seleção, no comentário, na observação do que há de melhor nas boas obras, na distinção entre obras boas e ótimas, na observação característica dos estilos, traços, técnicas e inventividade de cada artista e suas conseguintes formações para o alcance de suas singularidades. Eis o ponto elementar: Vasari não apenas

\footnotetext{
${ }^{8}$ N.a.: Permito-me afirmar que a referida passagem do texto de Vasari inaugura sobre a compreensão do artista (artefici) de sua época uma mudança na semântica do termo similar àquela observada por Friedrich Nietzsche, em sua obra Genealogia da Moral, em relação ao termo bonus, cuja significação deixou de se referir ao heroico e ao nobre romano (em proximidade com a interpretação grega de arché), para designar, com o advento do cristianismo, uma semântica do termo bom que é da mesma ordem de nosso entendimento moral na modernidade (Cf. NIETZSCHE, 1998, p.23).
} 
enobrece a arte daqueles 'artífices' especiais, ele faz observar que de fato tais obras são singulares e merecem um apreço diverso. E é tão-somente sob esse princípio, por sinal, que se justificaria o empenho vasariano em estabelecer uma narrativa histórica do desenvolvimento da prática daqueles artistas (artefici). Cito Danto:

\begin{abstract}
Não que aquelas imagens [anteriores a 1400 d.C., ou, mais especificamente, que antecedem ao Renascimento] deixassem de ser arte em um sentido amplo, mas serem arte não fazia parte de sua produção, uma vez que o conceito de arte ainda não havia surgido de fato na consciência geral, e essas imagens - ícones, realmente desempenhavam na vida das pessoas um papel bem diferente daquele que as obras de arte vieram a ter quando o conceito finalmente emergiu e alguma coisa como considerações estéticas começaram a governar nossas relações com elas. [...] Teria, então, havido uma profunda descontinuidade entre as práticas artísticas antes e depois da era da arte ter se iniciado, uma vez que o conceito de artista não fazia parte da explicação das imagens devotas, mas é claro que o conceito de artista se tornou central na Renascença, a ponto de Giorgio Vasari ter escrito um grande livro sobre a vida dos artistas (1997, p.3).
\end{abstract}

Danto não tem por pretensão afirmar que no ano de 1400 tenha havido uma mudança abrupta no entendimento da arte como ofício manual para a arte como criação autônoma (tal como não houve uma mudança abrupta em 1964 com o fim da narrativa histórica da arte por causa das Brillo Boxes de Andy Warhol). O que está em jogo, para o pensador de Ann Arbor, é que as condições históricas nas quais a arte passa a existir no Renascimento (tal como na segunda metade do século XX em relação ao seu fim histórico) denotam que a prática da arte sofreu naquele período uma nova forma de compreensão, cujo "Le Vite" vasariano demonstra a relevância alcançada por aquela atividade (naquele e a partir daquele período). É sob essa perspectiva de uma mudança das condições históricas da arte que o pensamento dantiano identifica, não como uma ação individual deliberada, mas como sintoma das condições da arte em uma época, o marco representativo do texto de Vasari, visto que este, "ao escrever uma primeira grande história da arte", de acordo com a qual "a arte seria a conquista progressiva da aparência visual, do domínio de estratégias por meio das quais o efeito das superfícies visuais do mundo no sistema visual dos seres humanos poderia ser replicado mediante superfícies pintadas eu afetassem o sistema visual da mesma maneira que o faziam as superfícies visuais do mundo" (Ibidem, p.48) estabeleceu uma espécie de novo paradigma para a atividade dos artífices. Dito de outra maneira, para Danto o texto de Giorgio Vasari dá início a uma forma de narrativa sobre a arte baseado no conceito de representação mimética, isto é, em que se dá uma corporificação de significado sobre os objetos, sendo tal corporificação de ordem da representação mimética, e em que as condições históricas sob as quais aqueles objetos passam a ser fruídos não apenas como imagens devotas oriundas de um processo meramente artesanal, 
mas enquanto objetos cujo qualitativo de desenvolvimento mimético adquirem um estatuto que os difere das demais produções dos artífices.

\section{As transformações da prática da arte no Cinquecento e a relevância das observações de Giorgio Vasari}

Um argumento que poderia ser apresentado, aqui, em contraposição ao peso atribuído por Danto ao papel de "Le Vite" no advento da era histórica da arte, consiste em argumentarmos que em Vasari e em sua época o entendimento moderno de arte não se encontra totalmente desenvolvido, ao passo que em outro período histórico, notadamente o século XVIII, um conjunto de inovações no trato artístico e filosófico teriam feito a arte - muito mais do que no Renascimento - adquirir um significado mais coerente com o de nossa época.

O século XVIII, de fato, é bastante representativo para o modo como compreendemos a arte nos dias atuais. É no início daquele século, por exemplo, que a pintura e a escultura deixaram de ser socialmente - e nos mais amplos sentidos - espécies de ofícios comuns, tornando-se áreas do conhecimento como outros campos dos saber, como a filosofia, e passaram a ser ensinadas nas universidades sob o nome de Belas Artes. Conseguinte ao emprego da nova nomenclatura que diferencia as Belas Artes dos ofícios artesanais, o estudo acadêmico das artes passou a demandar exposições anuais das obras de seus membros, estabelecendo uma era de salões de artes em que os artistas não necessitavam mais responder aos desejos específicos dos antigos mecenas, mas surpreender um determinado tipo de público a partir de criações autônomas, cujos motivos passaram a incorporar desde a criação de temas heroicos, casuais, paisagens, etc. Com os salões, a liberdade criadora ao mesmo tempo transpôs o rigor temático das oficinas medievais, e fez emergir a atividade do crítico de arte, cujo juízo a respeito das obras dialogava com o público o entendimento crítico da atividade artística como campo distinto ao das artesanias.

Obviamente, temos de chamar a atenção para o fato de que não se dá no século XVIII os primeiros escritos de crítica aos trabalhos artísticos. Platão, por exemplo, dedica parcela significativa de seus livros da República a questionar a atividade do artista, do poeta e do músico. No século I d.C., Filóstrato o Velho valeu-se do método sofista da écfrase (descriptio) para descrever e comentar junto aos seus discípulos o estudo de sessenta e cinco quadros expostos em uma galeria em Nápoles, destacando nestas não uma vinculação didática do exemplo homérico, mas o que há de maior virtuosismo retórico naquelas pinturas, que por sua vez retratavam cenas tradicionais da tragédia, da comédia, do mitológico, etc (FILÓSTRATO, 2016, p.5). No próprio “Le Vite”, de Vasari, encontramos diversas passagens de ordem crítica. 
Entretanto, o que está em questão é que com o advento dos salões de arte, das academias de Belas Artes e da prática da escrita crítica sobre arte, poder-se-ia argumentar que a partir do século XVIII encontramos um ambiente da prática artística muito mais próximo ao daquele que encontramos no ambiente artístico de nossa contemporaneidade do que em relação à Renascença.

Todavia, se é um fato que no século XVIII passou a existir um ambiente mais autônomo da arte, e de maior proximidade do significado da arte em relação ao nosso tempo, isto ocorre não porque a partir do século XVIII emergiu uma nova compreensão da arte em relação aos demais ofícios manuais, e sim porque naquele período a distinção da arte em relação a outros ofícios alcançou o seu pleno desenvolvimento. Que aqueles artistas do Renascimento não detivessem o mesmo tipo de compreensão profunda do debate estético sobre a arte tal como os artistas a partir do século XVIII, que não tivessem debatido na renascença qual a natureza da arte, isto não significa que estes últimos não tenham afastado a criação artística da mera artesania, nem tampouco que não tivessem, nesse processo de afastamento, dotado um conceito de natureza da arte (a mímesis) em seus empreendimentos criativos. Seja a participação desses artistas ainda primitiva na relação entre arte e estética, ou na arte como um objeto para apreciação desta ordem, o fato é que tal empreendimento já se consuma com aqueles artistas.

As diferenças entre os artistas do Renascimento e os antigos artífices não decorre tãosomente de uma comum preocupação com a representação mimética e seu desenvolvimento, mas de mudanças de paradigma concomitantes a esse processo. Historiadores da arte de campos conflitantes, como Arnold Hauser e Ernst Gombrich, por exemplo, concordam sobre a tese de que a partir da Renascença ocorreu uma clara mudança do entendimento da arte, dos artistas e de suas obras. Hauser observa que no início do Quattrocento a formação os artistas ainda se orientava nos mesmos princípios que condicionavam o trabalho dos artesãos comuns, não sendo eles treinados em escolas, mas em oficinas, e tendo por instrução a prática, e não a teoria. "Os artistas" daquele período "ainda são inteiramente gente do povo, são considerados artesãos de um grau superior, e suas origens sociais e educação não os fazem diferentes em nada dos elementos pequeno-burgueses das guildas" (tipos de associações de artesãos e mercadores que supervisionam a prática do artesanato), "sendo que muitos dos proprietários dessas oficinas agiam mais como homens de negócio do que artistas" (Hauser, 2003, p.322).

De acordo com o historiador húngaro, esse espírito artesanal que dominou aquele período pode ser expresso no fato de que "os ateliês dos artistas aceitavam encomendas de pouca importância, de natureza puramente técnica", visto que "além de quadros eram 
produzidos brasões de armas, bandeiras, tabuletas, trabalhos de marcenaria, entalhes em madeira pintados, padrões para tapeçarias e bordados, objetos decorativos para ocasiões festivas", dentre outras coisas (Ibidem, p.325). Por sua vez, entretanto, para Hauser é com a crescente demanda de obras de arte naquele período que começa a ascensão do artista do nível de artesão pequeno-burguês para o de trabalhador intelectual livre, o que passa a acontecer notadamente com a disputa de artistas mais renomados pelas cortes - e o consecutivo aumento de seus ganhos - a emancipação desses ilustres artistas do domínio das guildas, a busca de instrução teórica e erudição por esses personagens etc. que passaram a estabelecer uma espécie de aliança com os humanistas. Cito Hauser:

A emancipação dos pintores e escultores dos grilhões das guildas e sua ascensão do nível do artesão para o do poeta e do letrado foram atribuídas à sua aliança com os humanistas; o apoio que receberam destes explica-se, por outro lado, pelo fato de os monumentos literários e artísticos da antiguidade formarem uma unidade indivisível aos olhos desses entusiastas, os quais, ademais, estavam convencidos de que os poetas e artistas plásticos da antiguidade clássica eram tidos em igual respeito. [...] E fizeram com que sua própria época - e toda a posteridade até o século XIX acreditasse que o artista que jamais fora alguma coisa além de um mero mecânico aos olhos da comunidade, compartilhava com o poeta as honras do divino privilégio. [...] Os artistas também desejaram a amizade dos humanistas, não com o propósito de quebrar a resistência das guildas, mas para justificar a posição econômica que já tinham conseguido para si mesmos aos olhos da classe alta, dominada pela mentalidade humanista [...]. Para os artistas, os humanistas eram os avalistas de seu status intelectual. [...] Foi essa relação mútua que deu origem à concepção da unidade das artes, que hoje consideramos axiomática, mas que era desconhecida antes da Renascença (Ibidem, pp.330-332)

Gombrich, por sua vez, embora opte por destacar que a descoberta de desenvolvimentos técnicos que emergiram a partir do século XIV (mas, principalmente, do XV) como sendo responsáveis não apenas por conflitos com os antigos métodos de criação, mas também em relação à necessidade de seus artistas justificarem aos seus patronos os seus empreendimentos, observa que o advento da produção mimética causou enorme fascínio tanto entre os artistas (artefici) quanto nos mecenas, instigados com a ideia de que a arte pudesse ser usada não só para contar a história sagrada de modo emocionante, mas também para espelhar um fragmento do mundo real em algum suporte bidimensional ou escultórico (GOMBRICH, 2013, p.183). "Talvez o resultado mais imediato dessa grande revolução artística", prossegue o historiador da arte austríaco, "tenha sido que por toda parte os artistas se puseram a experimentar e pesquisar efeitos novos e impactantes", de tal modo que "esse espírito de aventura que dominou a arte do século XV veio marcar uma efetiva ruptura com a Idade Média” (Idem).

Os exemplos de Hauser e Gombrich corroboram a argumentação de que as mudanças instituídas na arte pelos artistas (artefici) do Renascimento inauguraram não apenas uma 
mudança técnica no modo de a arte ver o mundo, mas também de o próprio mundo ver a atuação daquela atividade. Esse processo de desenvolvimento iniciado a partir do século XIV, entretanto, encontra seu real desenvolvimento quando o processo de amadurecimento técnico alcançou o seu auge na Alta Renascença, isto é, no século XVI, época em que as condições sociais dos artistas ilustres adquiriu um novo status, dentro do qual Giorgio Vasari se viu compelido a escrever o seu "Le Vite". De acordo com Gombrich:

O começo do século XVI, o Cinquecento, é o mais célebre período da arte italiana, e um dos maiores de todos os tempos. Foi a época de Leonardo da Vinci e Michelangelo, Rafael e Ticiano, Correggio e Giorgione, Dürer e Holbein no Norte, e muitos outros mestres famosos. [...] Assistimos ao surgimento desse contexto, entretanto, desde a época de Giotto. Sua fama atingiu um patamar tão alto que a Comuna de Florença se orgulhava dele e desejava que a torre do sino de sua catedral fosse projetada por esse renomado mestre. Tamanho orgulho por parte das cidades que disputavam os serviços dos maiores artistas para embelezar seus prédios e criar obras de fama duradoura foi um grande incentivo para que os mestres se empenhassem em superar os concorrentes - estímulo que já não era encontrado na mesma medida nos países feudais do Norte. Sobreveio então a era das grandes descobertas, quando os artistas italianos recorreram à matemática para estudar as leis da perspectiva e à anatomia para examinar a estrutura do corpo humano - e seus horizontes se ampliaram. $\mathrm{O}$ artista deixou de ser mais um artesão qualquer. Era um mestre em si, que só alcançaria fama e glória se explorasse os mistérios da natureza e as leis secretas do universo (Ibidem, p.215).

A passagem gombrichiana destaca um ponto elementar para o advento da compreensão do artista como um erudito, antecedendo em diversos aspectos a compreensão dada ao termo no século XVIII: já à época de Vasari, muitos artífices haviam dado início a um processo de estudo humanista, distanciando suas atividades em certa medida do mero fazer artesão, e tornando-se eles eles próprios grandes estudiosos. No fim do século XV, por exemplo, Leon Battista Alberti escreveu De re aedificatoria, inaugurando junto a toda uma revolução da prática arquitetônica um rigoroso estudo teórico para explicar suas conquistas. Ao longo de toda a sua carreira, Leonardo Da Vinci escreveu um conjunto de manuscritos que, logo após a sua morte, foram organizados por Francesco Melzi no Trattato della pittura. E, por sua vez, Michelangelo Buonarroti se tornou o primeiro artista vivo a adquirir o status de "Il Divino", a exemplo das cartas de Pietro Aretino e Vasari, ou por ter sido o primeiro artista vivo a receber a honra de ser biografado em vida por este último. Cabe lembrar, ainda, que já no século XVI, conforme observa Gombrich, os artistas italianos chamavam os locais de encontros entre eles de 'academia', com o objetivo de salientar a igualdade entre eles e os eruditos a quem tanto valorizavam (2013, p.365).

O papel de Michelangelo Buonarroti é crucial para o entendimento da passagem do artefici para o artista. Como bem notou HAUSER (2003, p.328), não é possível demarcarmos 
com precisão uma linha divisória entre a profissão artística e o puro artesanato, mas ela está de algum modo ligada à pessoa de Michelangelo, posto que enquanto no Quattrocento era costume requerer dos artistas algum tipo de avalista que prestasse garantia do cumprimento de contrato para a realização de alguma obra (pintura, escultura ou arquitetura, dentre os demais), com Michelangelo essa exigência se converteu em mera formalidade. O próprio Vasari contemporâneo e amigo de Michelangelo - já não considerava o trabalho artesanal compatível com o respeito que o artista deve a si mesmo.

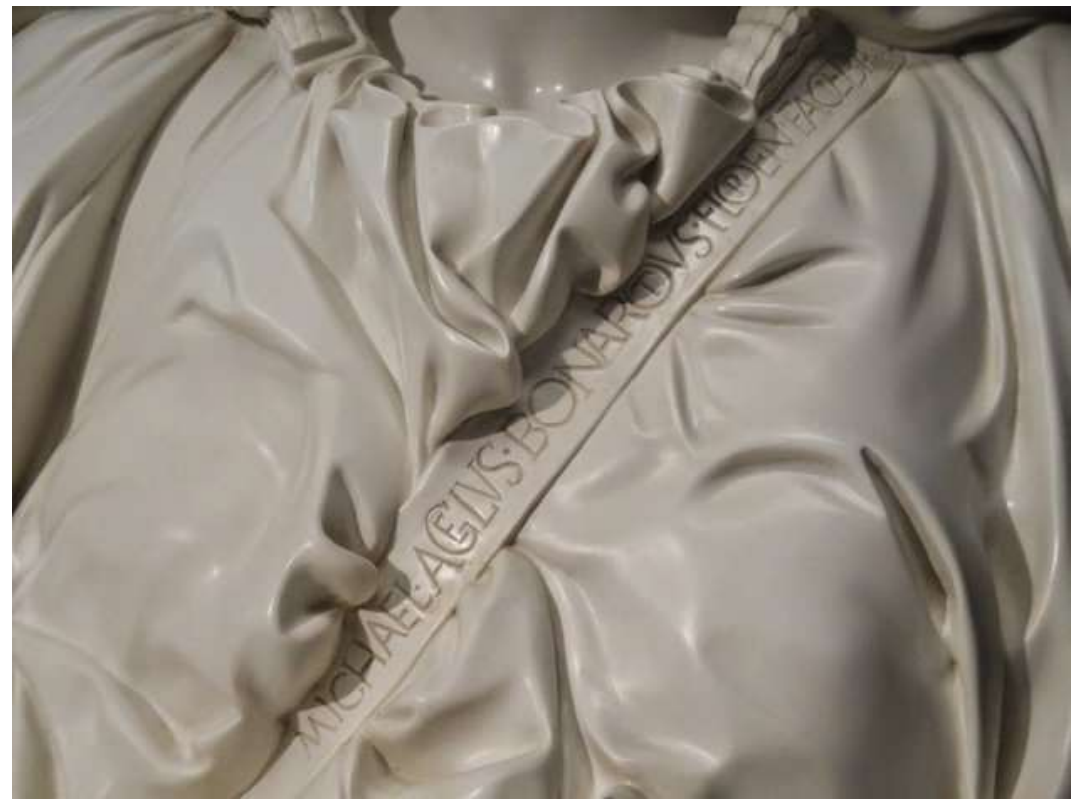

Fig.4: Michelangelo Buonarroti. Detalhe da assinatura do autor na fita que atravessa o peito da Virgem Maria, na escultura Pietà, de 1499.

A forma como Michelangelo Buonarroti foi considerado por seus contemporâneos o diferiu não apenas de outros ilustres artistas de sua época, mas instituiu de uma vez por todas a nova compreensão do artista - notadamente, é claro, em razão do gênio criativo e técnico de Michelangelo. Ao ser chamado 'Il Divino Michelangelo', sua época sagrou em vida e a um status inimaginável até então o prestígio de um artista (artefici). Esse título, afinal, não correspondia a dizer que sobre as obras e os temas do escultor, pintor e arquiteto se faria presente o universo da religiosidade cristã, não se tratava de uma adjetivação descritiva. Antes, era a honra de um título que em razão do evidente talento superior de Michelangelo o alçou para além do caráter humano, oferecendo-lhe uma atribuição que o equiparava às entidades divinas e garantindo para o artista e suas obras uma aura de singularidade e superioridade inalcançáveis para algum trabalho artesanal.

No "Le Vite" de Vasari, o estatuto alcançado por Michelangelo Buonarroti pode ser observado, por exemplo, quando o aretino afirma que "o Céu o mandou aqui embaixo para 
servir de exemplo na vida, nos costumes e nas obras, para que aqueles que se miram nele, imitando-o, possam aproximar-se da eternidade por meio da fama, da natureza, por meio das obras e do estudo e do Céu por meio da virtude", do mesmo modo "que ele sempre foi motivo de honra para a natureza e para o céu". Ademais, destaca o aretino, que "ninguém se admire por ter eu descrito a vida de Michelangelo, estando ele ainda vivo, pois, como se espera que ele nunca morra, pareceu-me conveniente contribuir um pouco para sua honra" (Vasari, 2011, p.739).

A divindade elogiosa atribuída em vida por Vasari e seus contemporâneos a Michelangelo é bastante simbólica do distante caráter que aquele artista adquiriu em relação ao tradicional trabalho dos artífices nas oficinas, distanciando-o não apenas do fazer daquela antiga função que outros artistas seus contemporâneos já haviam se proposto pela erudição e apuro técnico a se afastarem, como também por ser Michelangelo o personagem que inaugurou a perspectiva do artista dotado daquilo que séculos mais tarde seria chamado de gênio.

Porém, não está apenas no status social do artista florentino o argumento de sua distinção, mas também em uma iniciativa adotada pelo artista em uma de suas obras. Como bem observam Zöllner e Thoenes, "quando, em 1499, isto é, em finais de Quattrocentos", Michelangelo "inscreveu numa obra de arte religiosa - a sua Pietà de Roma - uma assinatura (Fig. 4) que efetivamente transformou uma coisa que era na Antiguidade um sinal de humildade no seu oposto", este ato "marcou na verdade o início de uma nova era artística, que era mais do que um simples renascimento da Antiguidade (2017, p.67). De fato, ao inscrever na fita localizada junto aos seios da Virgem Maria a passagem "MICHAEL ANGELUS BONAROTUS. FLORENT. FACIEBA", isto é, "Miguel Angelo Buonarotus de Florença fez", o artista de Florença instituiu sobre um tipo de objeto que a tradição encarava como um feito artesanal um ato que inovou a compreensão do seu artefato. Ao assiná-lo, Michelangelo instanciou sua propriedade artística sobre aquele objeto singular, e o distanciou dos trabalhos artefatuais das eras passadas, dando início a uma era em que aqueles objetos passaram a ser compreendidos e admirados de uma nova forma. E, se alguém ainda pudesse objetar que Vasari, ao dar início ao processo de narrativa histórica do trabalho daqueles artistas (artefici) estaria empregando um termo relativo aos trabalhadores dos ofícios assegurados pelas guildas medievais, o fato é que aquele nome já não correspondia àquele sentido. Podemos, assim, concluir que se por um lado os artistas da Renascença eram ainda artefici, isto não significa que seus representantes mais emblemáticos não tivessem adquirido um novo status social, nem que a sociedade a eles 
contemporânea não os tivesse alçado a um novo estatuto, como bem soube observar o inaugural "Le Vite" de Giorgio Vasari.

\section{REFERÊNCIAS BIBLIOGRÁFICAS}

BELTING, Hans. A história da arte como esquema narrativo. In. O fim da história da arte. Tradução de Rodnei Nascimento. São Paulo: Cosac Naify, 2012.

CHIPP, Herschel B. (Org.). Teorias da arte moderna. Tradução de Waltensir Dutra. São Paulo: Martins Fontes, 1988.

DANTO, Arthur C. The Artworld. In. The Journal of Philosophy, v.61, n.19, 1964, pp.571-584.

DANTO, Arthur C. Marcel Duchamp and the end of taste: a defense of Contemporary Art. In. Tout-Fait: The Marcel Duchamp Studies Online Journal, Apr. 2000, pp.1-13. Acesso em outubro de 2020. Disponível em: <https://www.toutfait.com/marcel-duchamp-and-the-end-oftaste-a-defense-of-contemporary-art/>.

DANTO, Arthur C. After the end of art: Contemporary art and the pale of history. New Jersey: Princeton University Press, 1997.

FILÓSTRATO (O Velho). Eikones. Tradução parcial de Rogério Gimenes de Campos. In. Rapsódia, n.10, 2016, pp.05-17. Acesso em maio de 2018. Disponível em: <<http://www. revistas.usp.br/rapsodia/issue/view/9440>>.

GOMBRICH, Ernst H. A história da arte. Tradução de Cristiana de Assis Serra. Rio de Janeiro: LTC, 2013.

HAUSER, Arnold. História social da arte e da literatura. Tradução de Álvaro Cabral. São Paulo: Martins Fontes, 2003.

NIETZSCHE, Friedrich. Genealogia da moral. Tradução de Paulo César de Souza. São Paulo: Companhia das Letras, 1998.

VASARI, Giorgio. Le vite de' più eccellenti architetti, pittori, et scultori italiani, da Cimabue insino a' tempi nostri (Nell' edizione per i tipi di Lorenzo Torrentino, Firenze 1550). Torino: Giulio Einaudi Editore, 1986.

VASARI, Giorgio. Le vite dei più eccellenti pittori, scultori e architetti (Edizione del 1569 edita a Firenze per i tipi dela Giunti). $3^{\text {a }}$ ed. Roma: Grandi Tascabili Economici Newton, 1997.

VASARI, Giorgio. Vidas dos artistas. Tradução de Ivone Castilho Bennedetti. São Paulo: Martins Fontes, 2011.

WÖLFFLIN, Heinrich. A arte clássica. Tradução de Marion Fleischer. São Paulo: Martins Fontes, 1990.

ZÖLLNER, Frank; THOENES, Christof. Miguel Ângelo: A obra integral de pintura, escultura e arquitetura. Colônia: Taschen, 2017. 